Mеталлофиз. новейшие технол. / Metallofiz. Noveishie Tekhnol. (C) 2016 ИМФ (Институт металлофизики 2016 , т. 38, № 12, сc. 1635-1654/ DOI: 10.15407/mfint.38.12.1635 им. Г. В. Курдюмова НАН Украины) Оттиски доступны непосредственно от издателя

Фотокопирование разрешено только

Напечатано в Украине.

в соответствии с лицензией

PACSnumbers: 68.35.Gy, 68.47.Gh, 68.55.J-, 68.55.Nq, 68.60.Dv, 81.65.Kn, 81.65.Mq

\title{
Real Time Test in Situ of Superalloy Oxide Scale Stress by Archimedes Curve Slice Moment Technique
}

\author{
Hai-tao Wang, Shao-mei Zheng, and Hua-shun Yu* \\ College of Mechanical Engineering, Qingdao University of Technology, \\ 11 Fushun Road, \\ 266033 Qingdao, China \\ "Key Laboratory for Liquid-Solid Structural Evolution and Processing of Materials, \\ Ministry of Education, Shandong University, \\ 17923 Jingshi Road, \\ 250061 Jinan, China
}

Stress is the direct cause of surface oxide scale exfoliation to ruin the protection for alloy matrix. Therefore, it is the key to study oxide scale mechanical behaviour for discovering the oxidation resistance of alloys. In this paper, a new kind of experimental method 'Archimedes curve slice moment technique' is studied to test in situ the real time oxide scale stress of ferro-based superalloy K273 during all the high-temperature oxidation. By the derived formula, the oxide scale stress $\sigma$ can be calculated precisely only by observing Archimedes curve slice real-time polar radius OC'. Having been oxidated for 5 hours at $800^{\circ} \mathrm{C}$, the oxide scale stress versus oxidation time is regressed to follow parabola equation strictly. As the oxides grow and the inner new oxides form in scales to press each other, the oxide scale stress is generated. Analysed by SEM, EDS and XRD, the oxide scale is compact composite structure made up of $\mathrm{Cr}_{2} \mathrm{O}_{3}$ and spinel (Fe, Ni, Mn) $\mathrm{Cr}_{2} \mathrm{O}_{4}$. The less oxide scale stress increment brings about the lower oxidation weight gain rate and the better oxidation resistance. Improved by the use of vacuum system, the Archimedes curve slice moment technique is going to test the oxide scale growing and thermal stresses qualitatively and quantitatively in situ all the time at high temperature.

Key words: ferro-based superalloy, oxide scale stress, oxidation resistance,

Corresponding author: Hai-tao Wang

E-mail: htwangsd@126.com

Please cite this article as: Hai-tao Wang, Shao-mei Zheng, and Hua-shun Yu, Real Time Test in Situ of Superalloy Oxide Scale Stress by Archimedes Curve Slice Moment Technique, Metallofiz. Noveishie Tekhnol., 38, No. 12: 1635-1654 (2016), DOI: $10.15407 /$ mfint.38.12.1635. 
Archimedes curve.

Напруження є безпосередньою причиною відшарування приповерхневої циндри, що призводить до руйнування захисту матриці стопу. Отже, вивчення механічної поведінки циндри є ключем до вивчення стійкости стопів до окиснення. В даній роботі розглянуто нову експериментальну методу міряння скручувального моменту для тонкого шару матеріялу, що був вирізаний за Архімедовою кривою, яка слугує для in situ дослідження в режимі реального часу напружень, що виникають через циндру у суперстопі на основі заліза К273 впродовж усього високотемпературного окиснення. Згідно з одержаним виразом, для точного розрахунку у режимі реального часу напружень $\sigma$, що виникають завдяки циндрі, достатньо лише спостереження за полярним радіюсом ОС' зразка, вирізаного за Архімедовою кривою. При дослідженні процесу окиснення протягом 5 годин за температури у $800^{\circ} \mathrm{C}$ залежність напружень через циндру від часу окиснення було зведено до рівняння параболи. По мірі росту оксиду та формування нових внутрішніх його шарів, які тиснуть один на одного, генеруються напруження за рахунок циндри. Аналіза, проведена методами CEM, EPC та РДА, показала, що циндра ущільнюється у композитну структуру, яка складається з $\mathrm{Cr}_{2} \mathrm{O}_{3}$ та шпінелі (Fe, Ni, Mn) $\mathrm{Cr}_{2} \mathrm{O}_{4}$. Зменшення напружень, що виникають за рахунок циндри, приводить до більш низької швидкости окиснення та підвищення стійкости до окиснення. Поліпшену використанням вакуумної системи методику in situ міряння скручувального моменту для зразків, вирізаних за Архімедовою кривою, якісно та кількісно перевірено шляхом дослідження зростання циндри та термічних напружень впродовж усього часу високотемпературного окиснення.

Ключові слова: суперстоп на основі заліза, напруження, що виникають через циндру, стійкість до окиснення, Архімедова крива.

Напряжения являются непосредственной причиной отслоения приповерхностной окалины, что приводит к разрушению защиты матрицы сплава. Следовательно, изучение механического поведения окалины является ключом к выяснению стойкости сплавов к окислению. В данной работе рассматривается новая экспериментальная методика измерения скручивающего момента для тонкого слоя материала, вырезанного по кривой Архимеда, служащая для in situ изучения в режиме реального времени напряжений, возникающих за счёт окалины, в суперсплаве на основе железа K273 в течение всего высокотемпературного окисления. Согласно полученному выражению, для точного расчёта в режиме реального времени напряжений $\sigma$, возникающих из-за окалины, достаточно лишь наблюдения за полярным радиусом $\mathrm{OC}^{\prime}$ образца, вырезанного по кривой Архимеда. При исследовании процесса окисления на протяжении 5 часов при температуре $800^{\circ} \mathrm{C}$ зависимость напряжений из-за окалины от времени окисления была сведена к уравнению параболы. По мере роста оксида и формирования новых внутренних его слоёв, давящих друг на друга, генерируются напряжения за счёт окалины. Анализ, проведённый методами СЭМ, ЭРС и РДА, показал, что окалина уплотняется в композитную структуру, состоящую из $\mathrm{Cr}_{2} \mathrm{O}_{3}$ и шпинели $(\mathrm{Fe}, \mathrm{Ni}, \mathrm{Mn}) \mathrm{Cr}_{2} \mathrm{O}_{4}$. 
Уменьшение напряжений, возникающих за счёт окалины, приводит к более низкой скорости окисления и повышению стойкости к окислению. Улучшенная использованием вакуумной системы методика in situ измерения скручивающего момента для образцов, вырезанных по кривой Архимеда, качественно и количественно проверена путём исследования роста окалины и термических напряжений на протяжении всего времени высокотемпературного окисления.

Ключевые слова: суперсплав на основе железа, напряжения, возникающие за счёт окалины, стойкость к окислению, кривая Архимеда.

(Received June 6, 2016)

\section{INTRODUCTION}

During high temperature oxidation, stresses arise naturally with oxide scales forming on the surface of superalloys, forcing oxide scales to wrinkle, break or even exfoliate off the matrix. The existing of stresses is the most important reason to ruin oxide scales and lose the oxidation resistance, so it greatly influenced on the life of superalloys in service. For a long time, researchers all over the world studied a lot for oxide scale stresses, many creative techniques were developed, among which pulling test [1-3], X-ray diffraction [4-6], and Raman spectroscopy [7-9] were the typical ones, making great efforts to study the generating mechanism of stresses and evaluate the protecting life of oxide scales for superalloys.

Pulling test was the earliest research technique in exploring oxide scale mechanical properties, simple, direct, and primitive, mainly engaged in detecting the adhesive forth between oxide scale and matrix, but poor in probing oxide scale stresses in situ. The pulling force results presented the comprehension of the adhesion strength with matrix and the binding strength by itself, a kind of static fuzzy data of multi forces, but not the accumulated dynamic stresses at real time in scales, so it was hard for real time test in situ of oxide scale stresses.

$\mathrm{X}$-ray diffraction was a kind of experimental method to detect the oxide scale stress indirectly. Although several decades went by, there were many uncertain factors and limitations to affect the oxide scale stress testing. X-ray diffraction could only measure the superficial stress, being insufficient for the thick oxide scale stress because of weak penetrability. In addition, the oxide scale stress was calculated by difference of diffraction peak drifting, which depended on the purity of materials. The diffraction peak matched with the standard PDF card without stress or impurity. Then, the exact testing of inner stress would be affected by impurity or multidisturbing of materials. Therefore, X-ray diffraction was only suitable for the oxide scale stress testing of pure structure precisely and qualitatively, but not for the multi 
oxides or composite oxide scales.

Raman spectroscopy also tested oxide scale stress indirectly; the spectra band choice, spectra peak precise location, laser penetration and material purity all limited the accurateness of stress testing. For composite oxide scale stress testing, Raman spectroscopy could only detect it roughly, such as the stress distribution or direction, while the stress qualitative or quantitative testing is insufficient.

It is of great significance to study oxide scale stress of superalloys for its mechanical prediction in all kinds of conditions, theoretical calculation of strength, on-line controlling in use, life evaluation, and development of new high quality materials. How to test oxide scale stress scientifically is the key problem in the work, namely, by what means to measure the stress correctly and precisely. There is no way to illustrate the mechanism of oxide scale stress generating and scale exfoliating without mechanical properties analyses accurately and qualitatively. With long term of research work on ferro-based superalloys $[10,11]$, this paper studied a new technology called 'Archimedes curve slice moment technique', which is expected to realize the real time oxide scale stress testing of superalloys in situ.

\section{EXPERIMENTAL PROCEDURE}

\subsection{Experiment Principle of Archimedes Curve Slice Moment Technique}

Archimedes curve is the trajectory running from circle centre at even velocity along radial and circumferential directions at the same time. As shown in Figure 1, let $v$ be radial rate, $\omega$ circumferential angular rate, $\psi$ rotating angle at any point $K, \alpha$ the angle between tangent line $\mathrm{KL}$ and radial line $\mathrm{KO}$, so the ratio of radial rate to linear rate is $\operatorname{tg} \alpha$ according to Archimedes curve characteristics:

$$
\operatorname{tg} \alpha=\mathrm{KO} \frac{\omega}{v} .
$$

Let the time running from circle centre to any point $\mathrm{K}$ be $t$. Then, $\mathrm{KO}=v t, \psi=\omega t$, and the formula (1) becomes (2):

$$
\operatorname{tg} \alpha=\mathrm{KO} \frac{\omega}{v}=\frac{v t \omega}{v}=\omega t=\varphi .
$$

When the metal is made to be Archimedes curve slice, being fixed at the start point $\mathrm{O}$ and put horizontally, it will bend and deform by the oxide scale stress torque during high temperature oxidation. Three dimensional stresses at any point $K$ on Archimedes slice surface come into being, as shown in Fig. $2, \sigma_{x}$ is the tangent line longitudinal stress, 


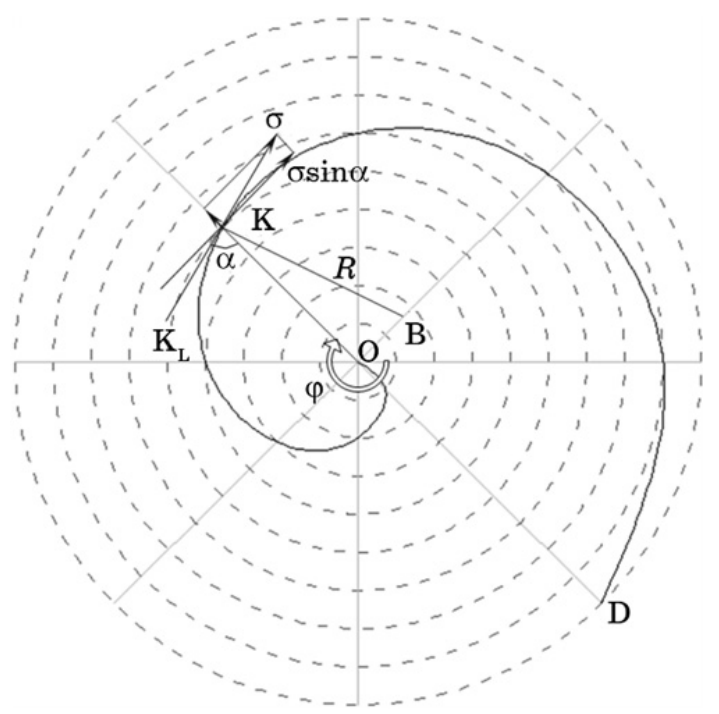

Fig. 1. Track analysis of Archimedes curve.

$\sigma_{y}$ the tangent line transversal stress, and $\sigma_{z}$ the normal line stress. Oxide scales grow on both front and back sides of Archimedes curve slice in the same oxidation conditions, so stresses at any point share the same size but different directions, which should be discussed according to different cases.

For the normal line stress $\sigma_{z}$, its direction varies with the first derivative $d y / d x$ tendency of rectangular coordinates $(x, y)$ on Archimedes curve, namely the positive or negative sign of the second derivative $d^{2} y / d x^{2}$. If the front side scale is convex, its $d y / d x$ decreases gradually, and $d^{2} y / d x^{2}<0$; on the contrary, the concave scale on backside leads to increasing $d y / d x$, and $d^{2} y / d x^{2}>0$. Therefore, at any point on Archimedes curve slice, the oxide scale normal line stresses on front and

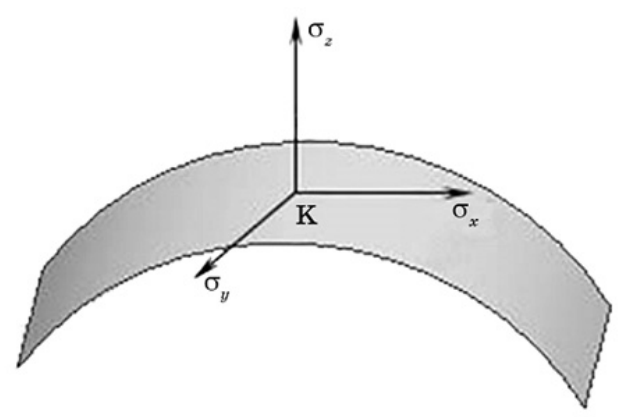

Fig. 2. Oxide scale stress analysis at any point K on Archimedes curve slice. 


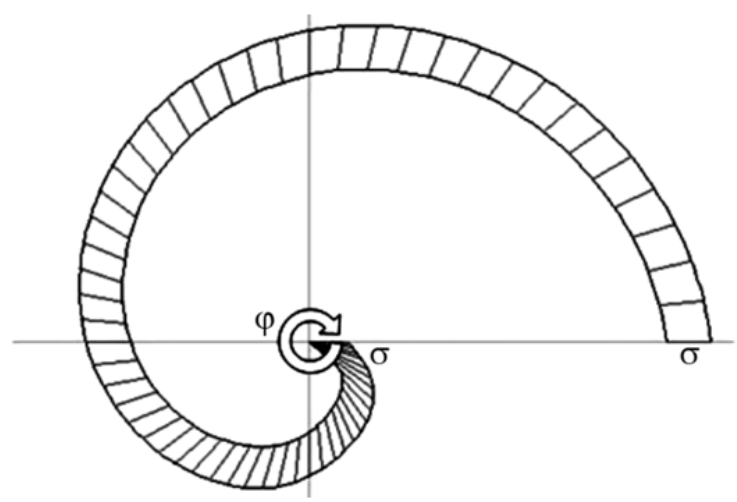

Fig. 3. Oxide scale stress distribution of Archimedes curve slice.

backsides share the same size and opposite directions, of which one is centripetal, and the other is centrifugal, as a result, there is no moment on slice matrix because of normal line stresses counteracting at any point of Archimedes curve slice.

For the tangent line longitudinal stress $\sigma_{x}$, its direction is related to the first derivative $d R / d \varphi$ of polar coordinate $(R, \varphi)$, namely the positive or negative sign of the second derivative $d^{2} R / d \varphi^{2}$. As shown in Figure 1, the radius $R$ increases gradually along Archimedes curve slice:

$$
R=\mathrm{KB}=\frac{\mathrm{KO}}{\sin \alpha}=\frac{v \operatorname{tg} \alpha}{\omega \sin \alpha}=\frac{v}{\omega \cos \alpha}=\frac{v}{\omega} \sqrt{\operatorname{tg}^{2} \alpha+1}=\frac{v}{\omega} \sqrt{\varphi^{2}+1} .
$$

Therefore, the first derivative of radius $R$ at any point $\mathrm{K}$ was $\frac{d R}{d \varphi}=\frac{v \varphi}{\omega \sqrt{\varphi^{2}+1}}$, increasing gradually with angle $\varphi$, nearly to be a constant $v / \omega$, namely $d^{2} R / d \varphi^{2}>0$. Therefore, at any point on Archimedes slice, the scale tangent line longitudinal stresses on front and backsides share the same size and direction, that the acting forces on Archimedes curve slice added each other.

For the tangent line transversal stress $\sigma_{y}$, its direction is always vertical to the longitudinal stress or the normal line stress, also vertical to the slice placing ground; so, there is no moment on Archimedes curve slice in the placing horizontal plane.

In a word, among three dimensional direction stresses, only tangent line longitudinal stress $\sigma_{x}$ affects the slice bending in the placing horizontal plane. In the same oxidation conditions, the oxide scale thickness is even and same everywhere, and stresses at any point are isotropic, so the three dimensional stresses are equal in size, $\left|\sigma_{x}\right|=\left|\sigma_{y}\right|=\left|\sigma_{z}\right|$. It is enough to study one dimension stress, and the 


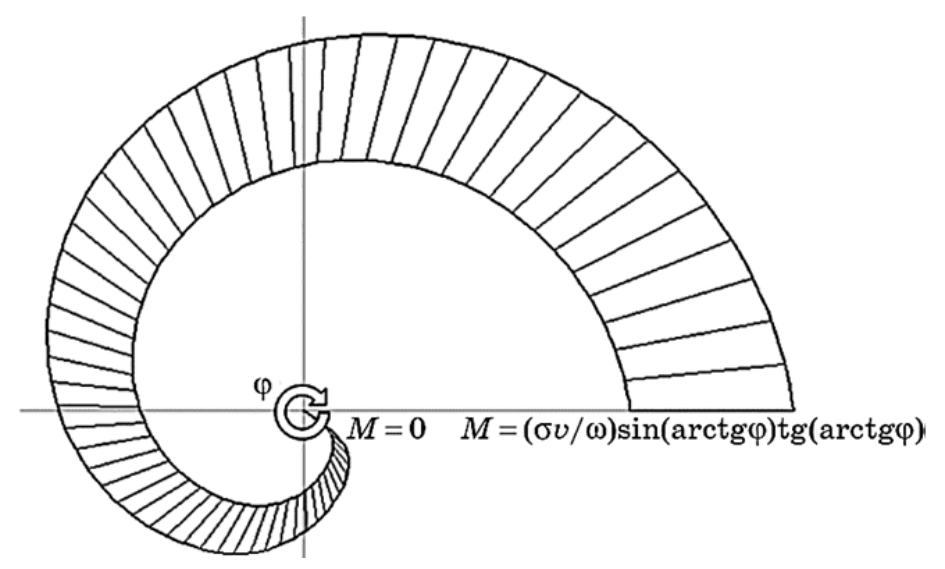

Fig. 4. Oxide scale stress moment distribution of Archimedes curve slice.

synthetic stress is $\sigma_{\mathrm{S}}=3^{1 / 2} \sigma_{x}$. In order to deduce formula clearly, the tangent line longitudinal stress at any point is marked $\sigma$, as shown in Fig. 1, then, the effective stress on bending moment is $\sigma \sin \alpha$, and the moment arm is $\mathrm{KO}$ :

$$
\mathrm{KO}=v t=v \varphi / \omega=(v / \omega) \operatorname{tg} \alpha .
$$

Therefore, the scale stress moment at any point $\mathrm{K}$ is $\mathrm{M}$ :

$$
M=\sigma \sin \alpha \mathrm{KO}=\frac{\sigma v}{\omega} \sin \alpha \operatorname{tg} \alpha .
$$

In formula (5), $\alpha=\operatorname{arctg} \varphi, \alpha$ increases with the curve rotating angle $\varphi$. The stress and moment distribution along Archimedes curve slice are shown in Fig. 3 and Fig. 4, respectively.

The stress $\sigma$ holds the same value all over the slice, and the moment varies from the minimum zero at start $O$ to the matrix $(\sigma v / \omega) \times$ $\times \sin (\operatorname{arctg} \varphi) \operatorname{tg}(\operatorname{arctg} \varphi)$ at the end D. So, the total moment $\sum M$ caused by oxide scale stresses on both front and back sides of the whole Archimedes curve slice can be calculated by integrating in angle $[0 ; \varphi]$ :

$$
\begin{aligned}
\sum M & =2 \int_{0}^{\varphi} \frac{\sigma v \sin \alpha \operatorname{tg} \alpha}{\omega} d \varphi=2 \int_{0}^{\varphi} \frac{\sigma v \varphi \sin \alpha}{\omega} d \varphi=2 \int_{0}^{\varphi} \frac{\sigma v \varphi \sqrt{1-\cos ^{2} \alpha}}{\omega} d \varphi= \\
& =2 \int_{0}^{\varphi} \frac{\sigma v \varphi \sqrt{1-\left(1+\operatorname{tg}^{2} \alpha\right)^{-1}}}{\omega} d \varphi=2 \int_{0}^{\varphi} \frac{\sigma v \varphi \sqrt{1-\left(1+\varphi^{2}\right)^{-1}}}{\omega} d \varphi= \\
& =2 \int_{0}^{\varphi} \frac{\sigma v \varphi^{2}}{\omega \sqrt{1+\varphi^{2}}} d \varphi=\frac{\sigma v}{\omega}\left[\varphi \sqrt{\varphi^{2}+1}-\log \left(\varphi+\sqrt{\varphi^{2}+1}\right)\right]_{0}^{\varphi} .
\end{aligned}
$$




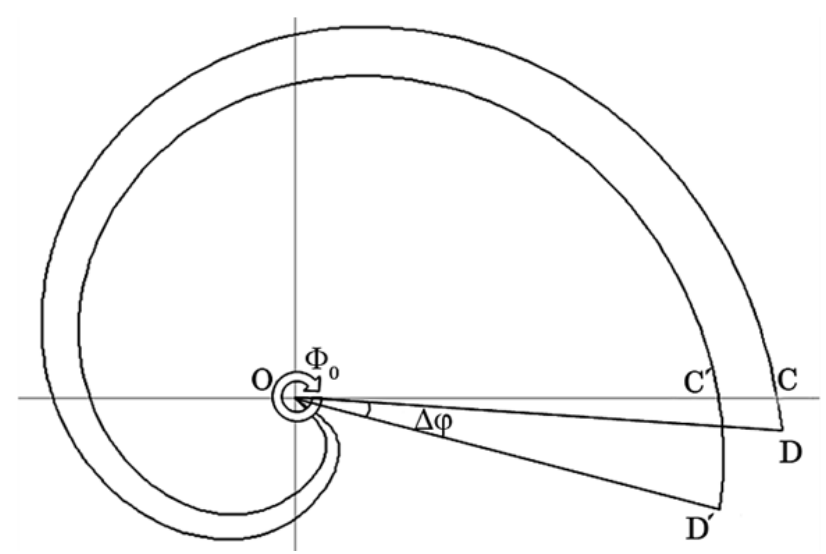

Fig. 5. The bending displacement of Archimedes curve slice by oxide scale stress.

Arc length is the product of radius and radian in a circle, hence the Archimedes curve arc differentiation is:

$$
d_{\mathrm{L}}=\operatorname{KOd} \varphi=v t d \varphi=\frac{v \varphi}{\omega} d \varphi .
$$

The Archimedes curve slice length integrated in angle $[0 ; \varphi]$ is:

$$
L=\int_{0}^{\varphi} \frac{v}{\omega} \varphi d \varphi=\left.\frac{v}{\omega}\left(\varphi^{2} / 2\right)\right|_{0} ^{\varphi} .
$$

The Archimedes curve slice deformed to bend in the horizontal plane by oxide scale stress with fixed total length and changing parameters radial rate $v$, angular rate $\omega$ and rotating angle range $\varphi$, as shown in Fig. 5, they turn from $v_{1}, \omega_{1}, \varphi_{0}$ to be $v_{2}, \omega_{2}, \varphi_{0}+\Delta \varphi$ respectively, in which $\Delta \varphi$ is the net angle variation, hence formula (8) is deduced to be:

$$
\begin{gathered}
L_{1}=\left.\frac{v_{1}}{\omega_{1}}\left(\varphi^{2} / 2\right)\right|_{0} ^{\varphi_{0}}=\frac{v_{1} \varphi_{0}{ }^{2}}{2 \omega_{1}}, \\
L_{2}=\left.\frac{v_{2}}{\omega_{2}}\left(\varphi^{2} / 2\right)\right|_{0} ^{\varphi_{0}+\Delta \varphi}=\frac{v_{2}\left(\varphi_{0}+\Delta \varphi\right)^{2}}{2 \omega_{2}}, \\
L_{1}=L_{2}, \\
v_{1} \varphi_{0}{ }^{2} /\left(2 \omega_{1}\right)=v_{2}\left(\varphi_{0}+\Delta \varphi\right)^{2} /\left(2 \omega_{2}\right), \\
\varphi_{0} \sqrt{v_{1} / \omega_{1}}=\left(\varphi_{0}+\Delta \varphi\right) \sqrt{v_{2} / \omega_{2}}, \\
\Delta \varphi=\varphi_{0}\left(\sqrt{v_{1} / \omega_{1}}-\sqrt{v_{2} / \omega_{2}}\right) / \sqrt{v_{2} / \omega_{2}}=\varphi_{0}\left(\sqrt{\left(v_{1} \omega_{2}\right) /\left(v_{2} \omega_{1}\right)}-1\right) .
\end{gathered}
$$


When metal bends by force, the torque $T$ and the angle $\Delta \varphi$ follows the formula (15):

$$
\Delta \varphi=\frac{T L}{E I},
$$

where $E$-metal elastic modulus, $L$-metal length, $I$-sectional moment of inertia $\left(I=b h^{3} / 12\right), b$-metal width, $h$-metal thickness.

Archimedes curve slice stops to bend with the total moment balance, meanwhile, the curve slice torque $T$ is equal to the scale stress accumulated moment $\sum M$ :

$$
T=\sum M
$$

$T$ can be obtained by solving formulas (9), (14) and (15):

$$
T=\frac{\Delta \varphi E I}{L}=\frac{\varphi_{0}\left(\sqrt{\frac{v_{1} \omega_{2}}{v_{2} \omega_{1}}}-1\right) E \frac{b h^{3}}{12}}{\varphi_{0}{ }^{2} v_{1} /\left(2 \omega_{1}\right)}=\frac{E b h^{3} \omega_{1}\left(\sqrt{\frac{v_{1} \omega_{2}}{v_{2} \omega_{1}}}-1\right)}{6 \varphi_{0} v_{1}} .
$$

When curve slice rotates angle $\Delta \varphi$ by scale stress, namely in the area $\left[0 ; \varphi_{0}+\Delta \varphi\right]$, the accumulated oxide scale stress moment $\sum M$ can be calculated by formula (6):

$$
\begin{gathered}
\sum M=2 \int_{0}^{\varphi_{0}+\Delta \varphi} \frac{\sigma v_{2} \varphi^{2}}{\omega_{2} \sqrt{1+\varphi^{2}}} d \varphi=\left.\frac{\sigma v_{2} S}{\omega_{2}}\left[\varphi \sqrt{\varphi^{2}+1}-\log \left(\varphi+\sqrt{\varphi^{2}+1}\right)\right]\right|_{0} ^{\varphi_{0}+\Delta \varphi}= \\
=\frac{\pi(\mathrm{OC}) b \sigma v_{2}}{\omega_{2}}\left[\left(\varphi_{0}+\Delta \varphi\right) \sqrt{\left(\varphi_{0}+\Delta \varphi\right)^{2}+1}-\log \left(\varphi_{0}+\Delta \varphi+\sqrt{\left(\varphi_{0}+\Delta \varphi\right)^{2}+1}\right)\right] .
\end{gathered}
$$

For

$$
\varphi_{0}+\Delta \varphi=\varphi_{0}+\varphi_{0}\left(\sqrt{\left(v_{1} \omega_{2}\right) /\left(v_{2} \omega_{1}\right)}-1\right)=\varphi_{0} \sqrt{\left(v_{1} \omega_{2}\right) /\left(v_{2} \omega_{1}\right)},
$$

one can solve formula (18):

$$
\begin{gathered}
\sum M= \\
=\frac{\pi(\mathrm{OC}) b \sigma v_{2}}{\omega_{2}}\left[\left(\varphi_{0}+\Delta \varphi\right) \sqrt{\left(\varphi_{0}+\Delta \varphi\right)^{2}+1}-\log \left(\varphi_{0}+\Delta \varphi+\sqrt{\left(\varphi_{0}+\Delta \varphi\right)^{2}+1}\right)\right]= \\
=\frac{\pi(\mathrm{OC}) b \sigma v_{2}}{\omega_{2}}\left[\varphi_{0} \sqrt{\frac{v_{1} \omega_{2}}{v_{2} \omega_{1}}} \sqrt{\varphi_{0}{ }^{2} \frac{v_{1} \omega_{2}}{v_{2} \omega_{1}}+1}-\log \left(\varphi_{0} \sqrt{\frac{v_{1} \omega_{2}}{v_{2} \omega_{1}}}+\sqrt{\left.\varphi_{0}{ }^{2} \frac{v_{1} \omega_{2}}{v_{2} \omega_{1}}+1\right)}\right] .\right.
\end{gathered}
$$


It is possible to deduce a formula (16) by (17) and (20) as follows:

$$
\begin{gathered}
\frac{E b h^{3} \omega_{1}\left(\sqrt{\left(v_{1} \omega_{2}\right) /\left(v_{2} \omega_{1}\right)}-1\right)}{6 \varphi_{0} v_{1}}=\frac{\pi(\mathrm{OC}) b \sigma v_{2}}{\omega_{2}}\left[\varphi_{0} \sqrt{\frac{v_{1} \omega_{2}}{v_{2} \omega_{1}}} \sqrt{\varphi_{0}{ }^{2} \frac{v_{1} \omega_{2}}{v_{2} \omega_{1}}+1}-\right. \\
-\log \left(\varphi_{0} \sqrt{\frac{v_{1} \omega_{2}}{v_{2} \omega_{1}}}+\sqrt{\left.\varphi_{0}{ }^{2} \frac{v_{1} \omega_{2}}{v_{2} \omega_{1}}+1\right)}\right], \\
\sigma=E h^{3} \omega_{1}\left(\sqrt{\left(v_{1} \omega_{2}\right) /\left(v_{2} \omega_{1}\right)}-1\right)\left(6 \pi(\mathrm{OC}) \varphi_{0} v_{1} \frac{v_{2}}{\omega_{2}}\right)^{-1} \times \\
\times\left[\varphi_{0} \sqrt{\frac{v_{1} \omega_{2}}{v_{2} \omega_{1}}} \sqrt{\varphi_{0}^{2} \frac{v_{1} \omega_{2}}{v_{2} \omega_{1}}+1}-\log \left(\varphi_{0} \sqrt{\frac{v_{1} \omega_{2}}{v_{2} \omega_{1}}}+\sqrt{\left.\varphi_{0}{ }^{2} \frac{v_{1} \omega_{2}}{v_{2} \omega_{1}}+1\right)}\right]^{-1} .\right.
\end{gathered}
$$

In experiment, with the Archimedes curve slice scrimping, the radius $\mathrm{OC}^{\prime}$ at the rotating angle $\varphi=2 \pi$ could be observed at real time. $\mathrm{OC}^{\prime}=v_{2} t=v_{2}(2 \pi / \omega)$; so,

$$
\frac{v_{2}}{\omega_{2}}=\frac{\mathrm{OC}^{\prime}}{2 \pi},
$$

$v_{1} / \omega_{1}$ is the ratio of the initial radial velocity to the angular velocity, and the start length of Archimedes curve slice $\mathrm{OC}$ is $\mathrm{OC}=v_{1} t=$ $=v_{1}(2 \pi / \omega)$, hence,

$$
\frac{v_{1}}{\omega_{1}}=\frac{\mathrm{OC}}{2 \pi} .
$$

Therefore, formula (22) turns to be:

$$
\begin{aligned}
& \sigma=2 \pi E h^{3}\left(\sqrt{(\mathrm{OC}) /\left(\mathrm{OC}^{\prime}\right)}-1\right)\left(3 \varphi_{0}(\mathrm{OC})^{2}\left(\mathrm{OC}^{\prime}\right)\right)^{-1} \times \\
& \times\left[\varphi_{0} \sqrt{\frac{\mathrm{OC}}{\mathrm{OC}^{\prime}}} \sqrt{\varphi_{0}{ }^{2} \frac{\mathrm{OC}}{\mathrm{OC}^{\prime}}+1}-\log \left(\varphi_{0} \sqrt{\frac{\mathrm{OC}}{\mathrm{OC}^{\prime}}}+\sqrt{\left.\varphi_{0}{ }^{2} \frac{\mathrm{OC}}{\mathrm{OC}^{\prime}}+1\right)}\right]^{-1} .\right.
\end{aligned}
$$

The synthetic stress is $3^{1 / 2}$ times of the tangent line longitudinal stress of Archimedes curve slice. Thus,

$$
\begin{aligned}
& \sigma=2 \sqrt{3} \pi E h^{3}\left(\sqrt{(\mathrm{OC}) /\left(\mathrm{OC}^{\prime}\right)}-1\right)\left(3 \varphi_{0}(\mathrm{OC})^{2}\left(\mathrm{OC}^{\prime}\right)\right)^{-1} \times \\
& \times\left[\varphi_{0} \sqrt{\frac{\mathrm{OC}}{\mathrm{OC}^{\prime}}} \sqrt{\varphi_{0}^{2} \frac{\mathrm{OC}}{\mathrm{OC}^{\prime}}+1}-\log \left(\varphi_{0} \sqrt{\frac{\mathrm{OC}}{\mathrm{OC}^{\prime}}}+\sqrt{\left.\varphi_{0}{ }^{2} \frac{\mathrm{OC}}{\mathrm{OC}^{\prime}}+1\right)}\right]^{-1},\right.
\end{aligned}
$$

in which, $\sigma$ is oxide scale stress, $E$-slice metal elastic modulus, $h-$ Archimedes curve slice thickness, OC-Archimedes curve slice initial polar radius, $\mathrm{OC}^{\prime}-$ Archimedes curve slice real time polar radius, $\varphi_{0}-$ 
Archimedes curve slice initial rotating angle.

From above all, the scale stress $\sigma$ at any point of Archimedes curve slice could be calculated by equation (26) precisely only by observing $\mathrm{OC}^{\prime}$ length at real time in situ with that the other factors are given.

\subsection{Scheme Implementation}

(1) Making of Archimedes curve slice samples. The standard superalloy K273 with the composition Fe80Cr20Ni5Mn5 was selected to be the test alloys. At first, the purchased $\varnothing 30 \mathrm{~mm}$ superalloy round bar was melted and cast to be $\varnothing 100 \times 10 \mathrm{~mm}$ roughcasts by high frequency induction furnace TX-25, then the roughcasts were machined to be $\varnothing 100 \times 5 \mathrm{~mm}$ thick plates by $\mathrm{X} 52 \mathrm{~K}$ milling machine, and the plates were wire cut by DK7740F to be Archimedes curve slice at last, as shown in Fig. 6, of which the thickness was $h=0.4 \mathrm{~mm}$, width $b=5 \mathrm{~mm}$, initial radius velocity $v_{1}=2.5 \mathrm{~mm} / \mathrm{s}$, initial rotating angle velocity $\omega_{1}=0.314$ $\mathrm{s}^{-1}, \varphi_{0}=2 \pi$, surface roughness no less than $R a=0.8 \mu \mathrm{m}$.

Before being milling machined, the roughcasts were heated to $950^{\circ} \mathrm{C}$ for 5 hours, then cooled in furnace, eliminating the cast or structure stresses by complete annealing, after that rough machining and finish machining went on. Before wire cutting with no inner stress by electric-chemical machining, samples were annealed again at lower temperature $200^{\circ} \mathrm{C}$ to $300^{\circ} \mathrm{C}$ to remove mechanical machining stress. Such process guaranteed that there was no stress concentration in Archimedes curve slice to prevent the influence on the oxide scale mechanical properties detecting.

Before high temperature oxidation, slice samples surface were washed clean by alcohol, no milling or polishing by emery paper in case of stress concentration on sample surface.

(2) Oxide scale stress testing. Ferro-based superalloy scale stress was

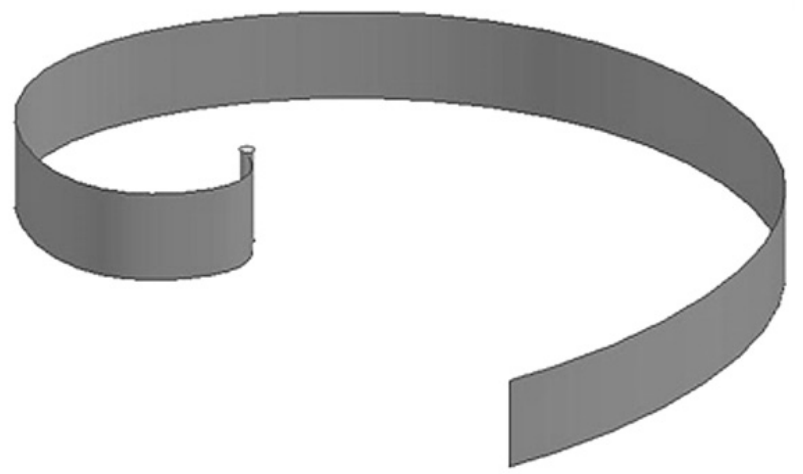

Fig. 6. Specimen of Archimedes curve slice. 
tested using oxide scale stress testing apparatus of Archimedes curve slice sample. As shown in Figure 7, the apparatus was made up of heating system SX2-8-13, temperature control system KYT, reading microscope JC-10, platinum rhodium thermocouple and so on. At first, the slice sample placed in resistance furnace were heated quickly to testing temperature, recording its beginning displacement OC, then, it was oxidated at the constant temperature, and the oxide scale growing stress came into being, resulting in sample slice deforming to bend, meanwhile, the scale stress was calculated by equation (26) with recording the displacement $\mathrm{OC}^{\prime}$ of slice directly at any oxidation real time.

(3) Oxide scale characterizations. After high-temperature oxidation, the oxidation weight gain was weighed to evaluate the oxidation resistance of superalloys by automatic photoelectric analysis level TG3288 $10^{-4} \mathrm{~g}$ according to Chinese Standard HB5258-2000. The morphology and structure of oxide scales were analysed by JSM-5800 type scan electrical microscope (SEM).

The elements existing in oxide scales were detected by Oxford INCA sight X energy disperse spectroscope (EDS). The oxide scales composition was tested by Rigaku Horizontal X-ray diffractometer (XRD) with use of radiation $\mathrm{CuK} K_{\alpha}, 40 \mathrm{kV}$ accelerating voltage, and $100 \mathrm{~mA}$ current.

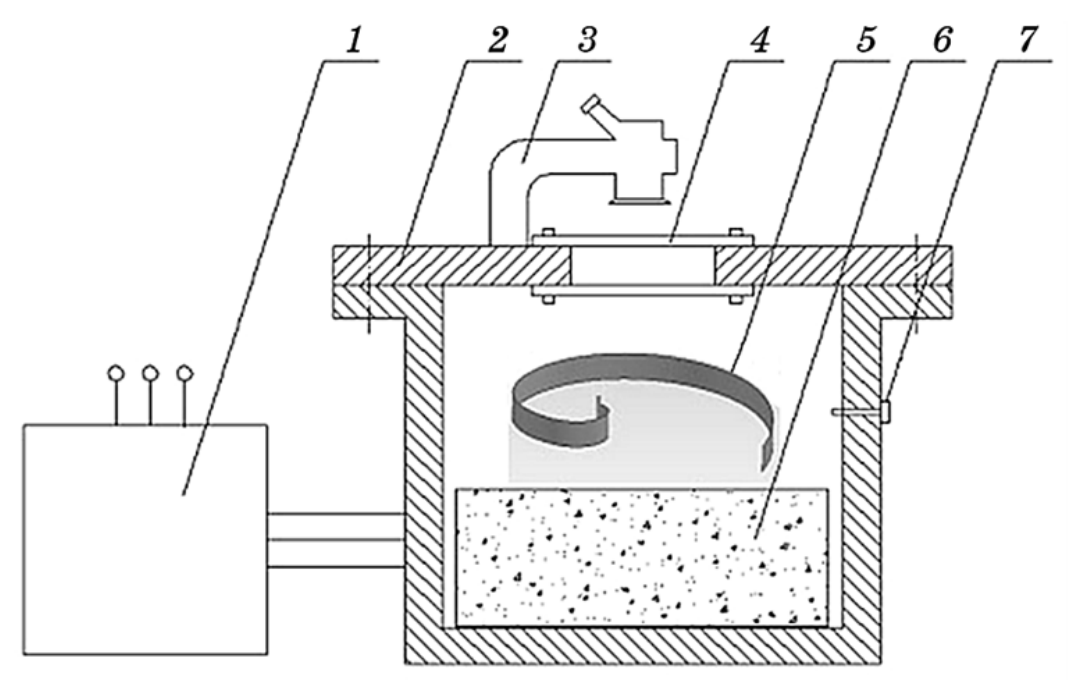

Fig. 7. Oxide scale stress testing apparatus of Archimedes curve slice sample: 1-KYT Temperature controller, 2-SX2-8-13 Resistance furnace, 3-JC-10 Reading microscope, 4-high temperature glass watching window, 5Archimedes curve slice sample, 6 -sample fixing station, 7-platinum rhodium thermocouple. 


\section{RESULTS AND DISCUSSION}

Having been oxidated at $800^{\circ} \mathrm{C}$ for 5 hours, the scale stresses of different oxidation time were calculated and the curve versus time was plotted in Fig. 8. Scale stresses increased gradually with time at high temperature, but the increment in each oxidation time decreased step by step, as shown, the slop of the curve was steeper at the beginning but trailed off later.

Regressing the stress data by the least square method and curve fitting, the equations were listed in Table 1 , the curve of scale stress versus time followed the parabolic law $(\sigma-a)^{2}=b t$.

The significance of regression equations and parameters in Table 1 were evaluated.

Given the significant level $\alpha=0.05$ for the curve of scale stress versus time at $800^{\circ} \mathrm{C}, F$ test for regression equation was calculated:

$$
F=(n-2) \frac{R^{2}}{1-R^{2}}=(5-2) \frac{0.9611^{2}}{1-0.9611^{2}}=36.3 \text {. }
$$

$F$ distribution critical value was consulted in mathematical statistics:

$$
F_{\alpha}(1, n-2)=10.13 \text {. }
$$

For $F>F_{\alpha}(1, n-2)$, hypothesis $H_{0}$ was refused, and $H_{1}$ was obtained. The regression equation of test alloy $(\sigma-3.1015)^{2}=38.8391 t$ was significant, and the curve confidence level arrived at $95 \%$.

The regression equation coefficient $t$ was calculated:

$$
T=R \sqrt{n-2} / \sqrt{1-R^{2}}=0.9611 \sqrt{5-2} / \sqrt{1-0.9611^{2}}=6.0269 \text {. }
$$

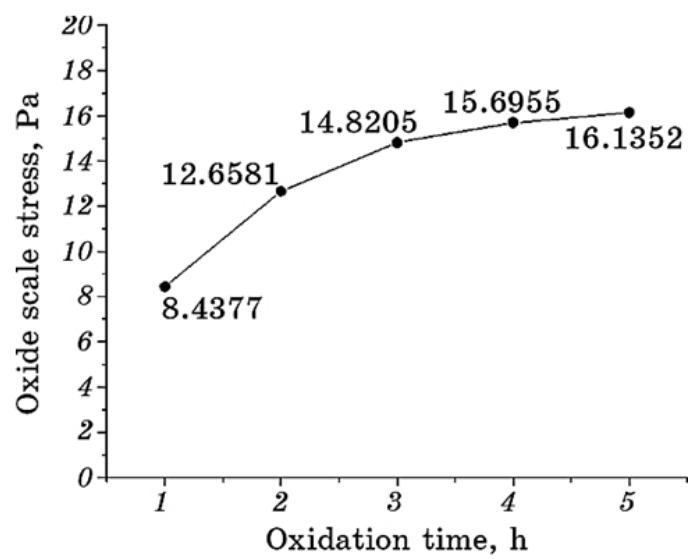

Fig. 8. Curves of oxide scale stress versus time of superalloy K273. 
$t$ distribution critical value was consulted in mathematical statistics:

$$
t_{0.5 \alpha}(n-2)=3.182 \text {. }
$$

For $T>t_{0.5 \alpha}(n-2)$, hypothesis $H_{0}$ was refused, and $H_{1}$ was obtained. The regression coefficients 3.1015 and 38.8391 of oxide stress equation were significant, and the confidence level reached $95 \%$.

In conclusion, the curve of oxide scale stress versus time of test alloy at $800^{\circ} \mathrm{C}$ followed the parabolic law strictly.

Early in the nineteen twenties and thirties, the relationship between oxide scale thickness and oxidation time had been studied a lot deeply by Tammann, Wagner et al. In oxidation atmosphere, the oxide scale thickness of metals increased with oxidation time, that for alloys with oxidation resistance, it rigorously followed the parabolic law $y^{2}=K t+C$, in which $y$ was oxidation scale thickness, $t$ oxidation time, $K$ and $C$ constants [12-14]. Such typical theory had deeply influenced the oxidation kinetics researches of alloys until now. The parabolic functional relationship of oxide scale stress versus time regressed above shared the same in nature with that of the oxide scale thickness. The coefficient $a$ and $b$ in parabolic law $(\sigma-a)^{2}=b t$ were determined synthetically by oxide scale composition, structure and density, oxidation temperature, oxygen partial pressure and so on. The function of oxide scale stress played an active role to guide detecting on line for superalloys. The prediction of oxide scale stress by time was beneficial for the monitoring of the exfoliation or ruining of oxide scale and oxidation resistance of alloys.

At high temperature, oxidation reaction took place on the surface of test alloys. On the basis of the principle of the lowest oxides forming Gibbs free energy, consulting Ellingham figures, the matrix elements $\mathrm{Fe}, \mathrm{Cr}, \mathrm{Mn}$, Ni were oxidated to be $\mathrm{FeO}, \mathrm{Cr}_{2} \mathrm{O}_{3}, \mathrm{MnO}$ and $\mathrm{NiO}$, respectively, such were the compositions of the first oxide scale at the beginning. On the one hand, with the oxidation reaction going on, the existed oxides grew bigger and bigger, during which the bigger oxides touched and pressed each other, as a result, the oxide scale stress arouse. On the other hand, new oxides came into being constantly attaching on the former existed oxides, if they grew on the outer surface of the oxide scales, with no concentration and naturally releasing of

TABLE 1. Regressing equations of oxide scale stress with time of superalloy K273.

\begin{tabular}{c|c|c|c}
\hline Temperature, ${ }^{\circ} \mathrm{C}$ & Regressing equation & $\begin{array}{c}\text { Correlation } \\
\text { coefficient }(R)\end{array}$ & $\begin{array}{c}\text { Regressing } \\
\text { time area, } \mathrm{h}\end{array}$ \\
\hline 800 & $(\sigma-3.1015)^{2}=38.8391 t$ & 0.9611 & $1-5$ \\
\hline
\end{tabular}




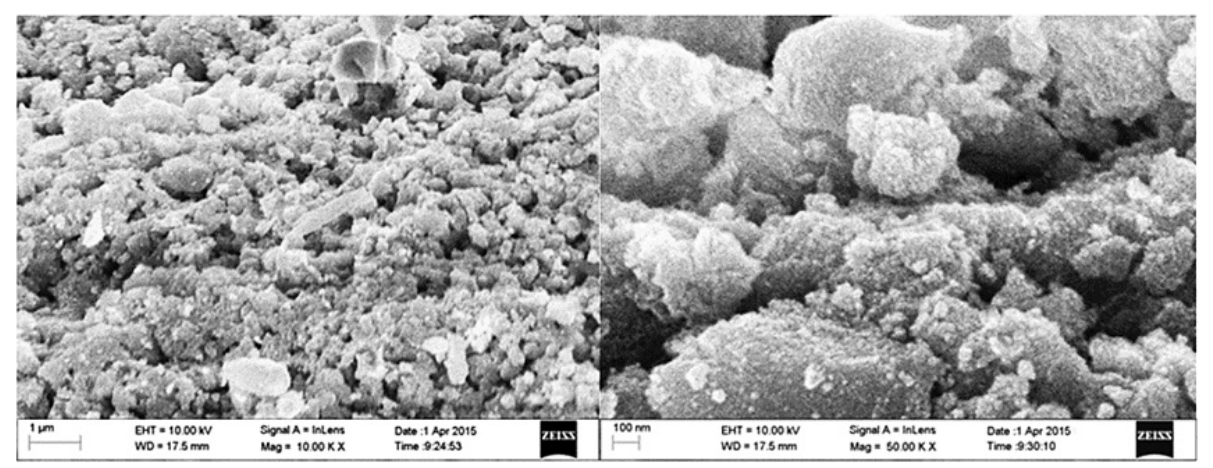

Fig. 9. SEM morphology of oxide scale of superalloy K273 after 5 hours oxidation at $800^{\circ} \mathrm{C}$.

growing force, there was no stress accumulated in oxide scales; but if the new oxides grew in the oxide scales, the growing brought squeezing on the matrix or oxide scales, such inner oxides growing was another main source of the oxide scale stress. To sum up, the oxides growing and the inner new oxides forming created stress in oxide scales. When such stress went up over the strength limitation of the oxide scale, meanwhile, the alloy matrix was rigid without any deformation, the scale would bear the full stress to break even exfoliate, speeding up the oxidation reaction, losing the oxidation resistance and matrix protection, which was as far as possible to be avoided for superalloys in use. In this experiment, the test alloys was made to be Archimedes thin slice, which was elastic to be easily bent by stress. Whereupon, being transformed to the deformation of the slice, the oxide scale stress was calculated by the bending displacement.

After being oxidated for 5 hours at $800^{\circ} \mathrm{C}$, the oxide scale morphology was analysed by SEM. In Figure 9, it was found that the scale structure was complete, compact and continuous, fully covering the matrix. The coarse oxides were the former generated ones as a result of continuous growing, during which the oxide scale stress accumulated. Otherwise, plenty of small oxide grains attaching on the coarse ones formed later, scattering all over the scales at random, of which the inner born ones also made lots of oxide scale stress. Analysed by EDS patterns and X-ray Diffraction, as shown in Figs. 10 and 11, the oxide scale composition of test alloys were made up of $\mathrm{Cr}_{2} \mathrm{O}_{3}$ and spinel, a kind of composite structure, in which $\mathrm{FeO}, \mathrm{NiO}$ and $\mathrm{MnO}$ did not existed alone, but were polymerized together in spinel (Fe, $\mathrm{Ni}, \mathrm{Mn}) \mathrm{Cr}_{2} \mathrm{O}_{4}$. Such compact highly composited structure endowed the oxide scale high oxidation resistance for superalloys.

It was found that the oxide weight gain rate in every oxidation time matched the oxide scale stress increment well. As shown in Figure 12, 


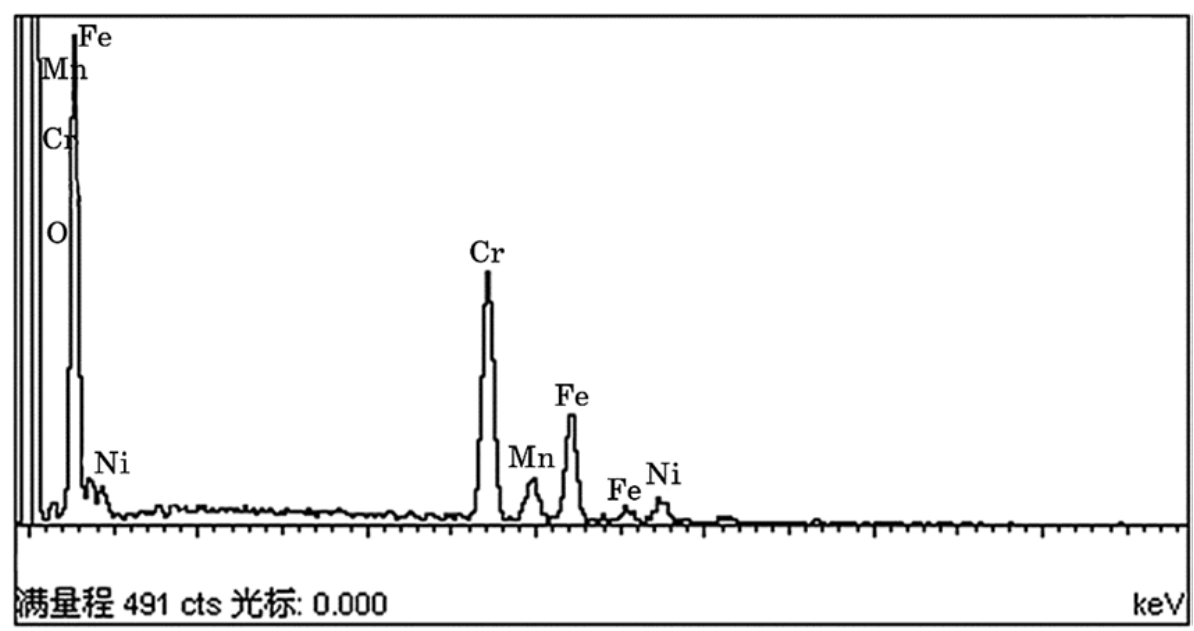

Fig. 10. EDS patterns of oxide scale of superalloy K273 after 5 hours oxidation at $800^{\circ} \mathrm{C}$.

less oxide scale stress increment corresponded to lower oxide weight gain rate and better oxidation resistance. Lower oxide weight gain rate meant less or slower oxidation reaction, and fewer new oxide producing. Therefore, there were fewer new oxides to draw or press each other in scales, resulting in smaller oxide scale stress increment.

According to formula (26), the oxide scale stress was calculated only by observing the Archimedes curve slice free terminal $\mathrm{OC}^{\prime}$, without detecting oxide scale thickness or weighing oxidation weight gain, without deriving the relationship of oxide scale thickness or oxidation weight gain versus time. Especially, it was after the oxidation to detect oxide scale thickness or oxidation weight gain of alloys, both of which the real time testing in situ could not be carried out anyway. Therefore, such Archimedes curve slice moment technique formula (26) was terse, clear and convenient, realizing the real time detecting and calculating of oxide scale stress in situ.

\section{EXPECTATION}

The oxide scale stress tested above is a synthetic value, including growing stress in oxides forming and thermal stress during heating or cooling. How to distinguish the growing stress and thermal stress is the key problem in the next research work.

(1). Testing of oxide scale growing stress. Based on oxide scale stress testing apparatus in Fig. 7, the vacuum system was introduced to test oxide scale growing stress. As shown in Figure 13, the new experiment device were made up of heating system, temperature controlling sys- 


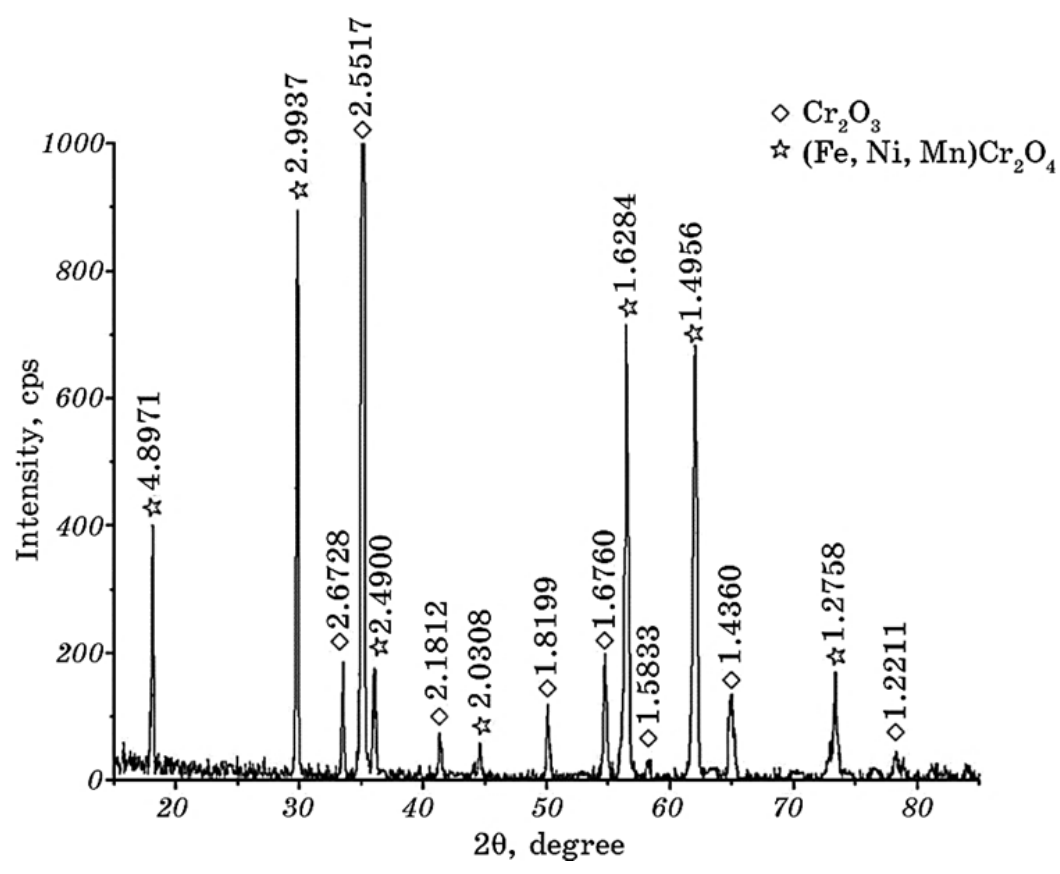

Fig. 11. X-ray diffraction of oxide scale of superalloy K273 after 5 hours oxidation at $800^{\circ} \mathrm{C}$.

tem, vacuum system, reading microscope, vacuum gage, valves, and so on. At first, the slice sample was heated to the given temperature in vacuum condition, then broke vacuum by opening air valve, and let the slice sample be oxidated in air for a certain time, during which the displacement of the slice were recorded every moment, and the oxide scale stress was worked out by formula (26). There was no temperature change, oxides formed at the same temperature with no thermal stress, so the stress measured was the pure oxide scale growing stress at given temperature.

The bending slice displacement could be read in situ at real time by long focus microscope directly through watching window fixed on the furnace.

(2). Testing of oxide scale thermal stress. Oxide scale thermal stress was tested after that for the growing stress. Having been observed the bending displacement for a certain time oxidation at given temperature, the slice sample cooled down to room temperature, during which the slice real time bending displacement was recorded and the scale stress at different temperature was calculated by formula (26). Such stress was the vector sum of the oxide scale growing and thermal stress, subtracting the growing stress calculated above, the leave was the pure thermal stress only by temperature changing. During the pe- 


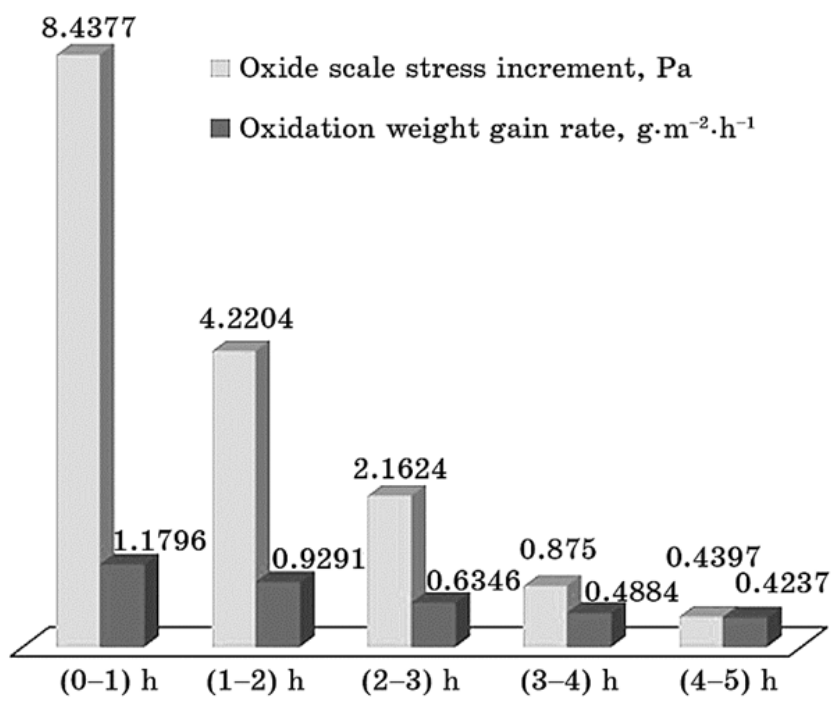

Fig. 12. Oxide scale stress increment and oxidation weight gain rate of superalloy $\mathrm{K} 273$ at $800^{\circ} \mathrm{C}$ in different time.

riod of cooling, no oxidation reaction occurred without heating, and no oxides formed. Therefore, no new oxide scale growing stress came into being, and the growing stress could be looked as a constant at every temperature, the same as that at the temperature from cooling. Eventually, the thermal stresses in oxide scale of slice samples in various temperature ranges could be obtained exactly.

Such Archimedes curve slice moment technique could observe the slice bending displacement in situ all the time in oxidation. Consequently, the oxide scale growing and thermal stresses would be both tested accurately at any temperature for a certain time, which was hard in the former research technologies.

\section{CONCLUSIONS}

1. A new method of Archimedes curve slice moment was studied to test superalloy oxide scale stress at real time in situ, in which the stress calculating formula was deduced to be:

$$
\sigma=\frac{2 \sqrt{3} \pi E h^{3}\left(\sqrt{(\mathrm{OC}) /\left(\mathrm{OC}^{\prime}\right)}-1\right)}{3 \varphi_{0}(\mathrm{OC})^{2}\left(\mathrm{OC}^{\prime}\right)\left[\varphi_{0} \sqrt{\frac{\mathrm{OC}}{\mathrm{OC}^{\prime}}} \sqrt{\varphi_{0}^{2} \frac{\mathrm{OC}}{\mathrm{OC}^{\prime}}+1}-\log \left(\varphi_{0} \sqrt{\frac{\mathrm{OC}}{\mathrm{OC}^{\prime}}}+\sqrt{\left.\varphi_{0}^{2} \frac{\mathrm{OC}}{\mathrm{OC}^{\prime}}+1\right)}\right]\right.},
$$

in which, $\sigma$ is oxide scale stress, $E$-slice metal elastic modulus, $h-$ Archimedes curve slice thickness, OC-Archimedes curve slice initial 


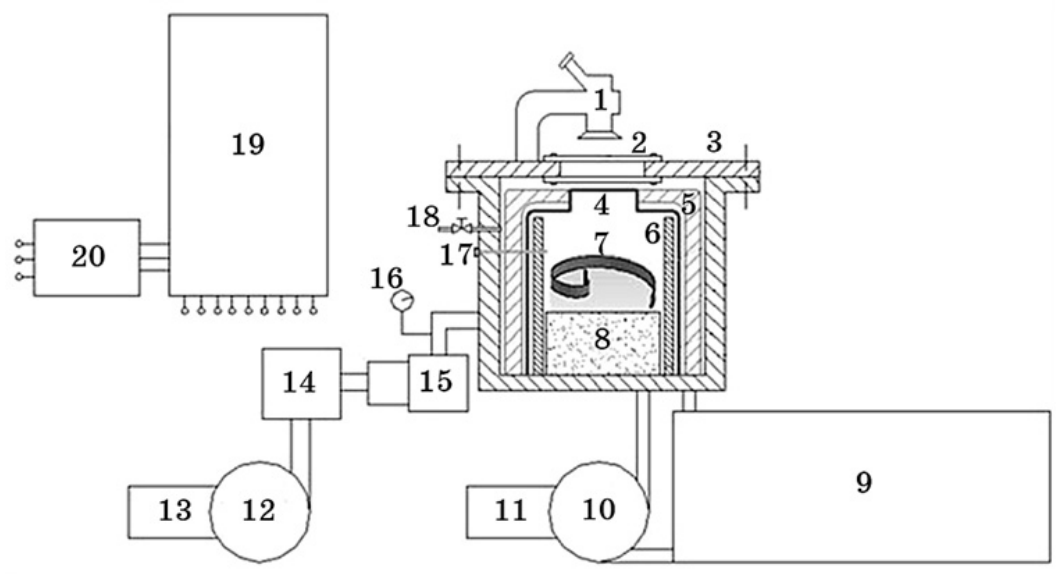

Fig. 13. Oxide scale stress testing apparatus with vacuum system of Archimedes curve slice sample: 1 -reading microscope, 2-watching windows, 3 vacuum furnace, 4 -high temperature quartz cover, 5 -insulating layer, 6 carbon tube heater, 7-Archimedes curve slice sample, 8- sample fixing station, 9-cooling water box, 10-cooling water pump, 11-electric motor, 12-vacuum pump, 13-electric motor, 14-convex cavity diffusion pump, 15-high vacuum butterfly bumpers, 16-vacuum pressure gage, 17platinum rhodium thermocouple, 18-air valve, 19-electrical control cabinet, 20-transformer.

polar radius, $\mathrm{OC}^{\prime}-$ Archimedes curve slice real time polar radius, $\varphi_{0}-$ Archimedes curve slice initial rotating angle.

2 . The curve of oxide scale stress versus time of superalloy K273 followed the parabolic law $(\sigma-3.1015)^{2}=38.8391 t$, strictly oxidated at $800^{\circ} \mathrm{C}$ in 5 hours.

3 . The oxides growing and the inner new oxides forming created stress in oxide scales.

4. Having been oxidated for 5 hours at $800^{\circ} \mathrm{C}$, the oxide scale composition of superalloy $\mathrm{K} 273$ was composed by $\mathrm{Cr}_{2} \mathrm{O}_{3}$ and spinel (Fe, Ni, $\mathrm{Mn}) \mathrm{Cr}_{2} \mathrm{O}_{4}$.

5 . The oxide scale stress increment matched with the oxide weight gain rate, the less stress increment, the lower oxidation weight gain rate, and the stronger oxidation resistance.

This research was financially supported by the Scientific Research Program of Shandong Higher Education of China (No. J14LA09) and the National Natural Science Foundation of China (No. 51307091).

\section{REFERENCES}

1. H. J. Engell und F. K. Peter, Archiv für das Eisenhüttenwesen, 28: 567 (1957) 
(in German).

2. $\quad$ K. Kendall, J.Phys. D: Appl. Phys., 4: 1186 (1971).

3. M. Schutze, Mater. Sci. Technol., 4: 407 (1988).

4. A. M. Huntz, J. L. Lebru, and A. Boumaza, Oxid. Metals, 33: 321 (1990).

5. C. Juricic, H. Pinto, D.Cardinali, M. Klaus, Ch. Genzel, and A. R. Pyzalla, Oxid. Metals, 73: 115 (2010).

6. J. L. Ruan, Y. M. Pei, and D. N. Fang, Acta Mechanica, 223: 2597 (2012).

7. J. Birnie, C. Craggs, D. J. Gardiner, and P. R. Graves, Corrosion Sci., 33: 1 (1992).

8. P. Y. Hou, J. Ager, J. Mougin, and A. Galerie, Oxid. Metals, 75: 229 (2011).

9. F. Yang, X. F. Zhao, and P. Xiao, Oxid. Metals, 81: 331 (2014).

10. Hai-tao Wang, Hua-shun Yu, Yu-qing Wang, Jing Zhang, Zhen-ya Zhang, and Zhi-fu Wang, Metallofiz. Noveishie Tekhnol., 31, No. 5: 701 (2009).

11. Hai-tao Wang, Ji-wen Tan, Chang-song Liu, and Hua-shun Yu, Metallofiz. Noveishie Tekhnol., 33, No. 6: 757 (2011).

12. G. Tammann, Z.Anorg. Chem., 111: 78 (1920).

13. C. Wagner, Z. Physik. Chem., B21: 25 (1933).

14. C. Wagner, Z. Physik. Chem., B32: 447 (1936). 